\title{
APLIKASI TEKNOLOGI PENDIDIKAN BAGI GURU DAN DOSEN
}

\author{
Suprayekti
}

\section{Abstract}

Educational technology as a discipline can be explained by theory and practice. Educational technology as a theory based with empiric evidence as result of research. Educational technology as a practice is a recipe use as an alternative solution for students learning problems

Teacher can apply learning recipe to optimize students learning result. This application used to help professional competence regarding the Undang-Undang Guru dan Dosen No. 14 Tahun 2005. Some of the applications are students' analysis, learning process and grading.

Kata Kunci: Teknologi Pendidikan, guru, dosen

\section{PENDAHULUAN}

Masalah belajar peserta didik pada jenis pendidikan formal sering diindikasikan dari prestasi belajarnya yang tidak mencapai standar kompetensi belajar mengajar, seperti hasil belajar UAN, indeks prestasi mahasiswa rendah. Faktor penyebab keadaan itu antara lain peserta didik tidak termotivasi selama pembelajaran berlangsung, peserta didik tidak memahami materi pelajaran yang disajikan guru/ dosen, atau peserta didik tidak dapat memahami cara guru/dosen menilai keberhasilan belajar.

Akibat dari penyebab tersebut adalah suasana pembelajaran menjadi tidak kondusif dan komunikasi peserta didik dengan guru/dosen terhambat. Dengan kata lain pembelajaran menjadi hampa. Oleh karena itu guru/dosen perlu mengenal peserta didik dari aspek karakteristiknya untuk keperluan pembelajaran, melaksanakan pembelajaran secara sistematis dan menilai hasil belajar secara sahih. Ketiga aplikasi pendidikan ini diharapkan dapat membantu guru/dosen dalam meminimalkan masalah belajar peserta didik dan meningkatkan kualitas kinerja guru/dosen dengan cara memodifikasi sesuai dengan kebutuhan lapangan.

\section{Masalah}

Berdasarkan paparan di atas, masalah yang dirumuskan adalah bagaimanakah aplikasi dari analisis peserta didik, pelaksanaan pembelajaran dan penilaian hasil belajar dilihat disiplin ilmu teknologi pendidikan?

\section{PEMBAHASAN}

Bagian ini akan mendeskripsikan analisis peserta didik, pelaksanaan pembelajaran dan penilaian hasil belajar.

\section{Analisis Peserta Didik}

Undang-Undang Sisdiknas No. 20 Tahun 2003 memberikan batasan peserta didik sebagai anggota masyarakat yang berusaha mengembangkan potensi diri melalui proses pembelajaran yang tersedia pada jalur, jenjang dan jenis pendidikan tertentu. Anggota masyarakat ini pada jalur formal merupakan individu yang berada dalam suatu ikatan interaksi belajar mengajar.

Di dalam jalur pendidikan formal, guru/dosen sangat penting mengenal dan memahami karakteristik peserta didik. Mengacu pada teori Seels dan Richey, karakteristik peserta didik merupakan satu bidang kerja dari kawasan desain pembelajaran. Hal ini berarti karakteristik peserta didik perlu dianalisis oleh guru/ dosen guna membantu bidang kerja perancangan sistem pembelajaran, perancangan pesan dan perancangan strategi pembelajaran. Dengan kata lain bila guru/dosen melakukan kegiatan analisis peserta didik, ia dapat merencanakan sistem pembelajaran, merencanakan materi pembelajaran dan strategi pembelajaran sesuai dengan kebutuhan peserta didik.

Manfaat kegiatan analisis peserta didik diperluas seperti digambarkan oleh Dick Carey, Kemp, Ely, Mollenda yaitu guru/dosen dapat mengembangkan evalusi hasil belajar. Analisis karakteristik peserta didik adalah kegiatan menguraikan ciri-ciri umum dan khusus peserta didik 
yang akan digunakan dalam pembelajaran. Heinich, Mollenda dan Russell mengemukakan tiga ciri peserta didik yang dapat dianalisis yaitu :

a. Karakteristik umum adalah ciri-ciri umum yang sama yang dimiliki oleh peserta didik seperti latar belakang sosial budaya, keadaan fisik (usia, tinggi badan, berat badan), minat, motivasi, kesiapan belajar, IQ.

b. Kompetensi awal yaitu kemampuan intelektual awal dari penguasaan peserta didik terhadap materi pelajaran.

c. Gaya belajar adalah cara peserta didik dalam memproses informasi yang dikaitkan dengan persepsi dan inderanya. Dalam hal ini De Porter mengkategorikan gaya belajar yang auditori, visual dan kinestetik

Karakteristik peserta didik dapat ditinjau dari sudut kecerdasan (Gardner), yaitu kecerdasan logis matematis, kecerdasan musikal, kecerdasan bahasa, kecerdasan interpersonal, kecerdasan intrapersonal, kecerdasan kinestetis, kecerdasan spasial, kecerdasan naturalis dan kecerdasan eksistensial.

Untuk memudahkan guru/dosen mengumpulkan data-data tentang karakteristik peserta didik, dapat digunakan dengan alat pengumpul data seperti angket, tes, wawancara. Setelah diperoleh deskripsi data, dilanjutkan dengan analisis yang disesuaikan dengan kebutuhan. Contoh aplikasi :

I. Kasus A

1. Peserta didik kelas VIII setelah diberikan angket motivasi belajar, diperoleh kesimpulan bahwa motivasi belajar rendah.

2. Guru dapat merencanakan strategi pembelajaran pada aspek teknik pembelajaran agar siswa termotivasi dengan upaya berikut :

a. Mengunakan metode pembelajaran bervariasi.

b. Mengunakan media untuk melengkapi materi pembelajaran.

c. Menggunakan humor dalam penyajian pembelajaran.

d. Menggunakan peristiwa nyata, perumpamaan, contoh-contoh.

e. Menggunakan teknik bertanya untuk melibatkan pebelajar.

f. Menjelaskan tujuan pembelajaran / kompetensi yang akan dicapai.

g. Menjelaskan manfaat dari pengetahuan yang akan dicapai.

h. Memberikan contoh, latihan, tes yang berhubungan dengan profesi. i. Menghadirkan nara sumber dari alumnus yang berhasil.

j. Menyusun materi menjadi bagian-bagian yang lebih kecil.

k. Menunjukkan persyaratan untuk berhasil.

1. Menggunakan kata-kata yang membangun.

$\mathrm{m}$. Mengatur pembelajaran dengan dengan strategi kontrak kuliah.

n. Mengemukakan cara mencapai kesuksesan prestasi belajar.

o. Memberikan umpan balik dalam berbagai situasi pembelajaran.

p. Menggunakan pujian / hukuman.

q. Memberikan kesempatan kepada pebelajar untuk mempraktekkan pengetahuannya.

r. Memberikan kesempatan kepada pebelajar berprestasi untuk membantu temannya.

s. Mengupayakan bantuan bimbingan kepada pebelajar yang belum berhasil.

t. Mendorong pebelajar untuk bangga dengan prestasi yang telah dicapainya.

II Kasus B

1. Mahasiswa tahun pertama berasal dari sekolah menengah umum dan kejuruan. Dominan gaya belajarnya berbeda seperti tabel berikut :

\begin{tabular}{|c|c|c|}
\hline Gaya belajar auditori & Gaya belajar visual & Gaya belajar kinest \\
\hline $50 \%$ & $30 \%$ & $20 \%$ \\
\hline
\end{tabular}

2. Dosen dapat merencanakan materi perkuliahan dengan mengolah pesan yang melibatkan indera pendengar, indera penglihatan dan indera gerakan tubuh/otot. Misalnya $50 \%$ materi diolah melalui presentasi/ceramah, dan $50 \%$ dibantu transparasi dan simulasi.

Aplikasi lainnya dapat diidentifikasi dari contoh yang ada. Misalnya bagaimana bila peserta didik memiliki kecerdasan jamak, atau kecerdasan intelektual (IQ) relatif sama. Kegiatan ini terus menerus harus dilakukan agar kompetensi paedagogik guru/dosen meningkat, sehingga ia mengenal karakteristik siswanya satu persatu.

\section{Pelaksanaan Pembelajaran}

Pembelajaran adalah proses yang sengaja dilakukan oleh guru/dosen dalam mengupayakan peserta didik belajar dengan harapan tujuan pembelajaran / kompetensi tercapai secara efektif 
dan efisien. Proses yang dimaksud disini adalah mulai dari persiapan mengajar, pelaksanaan proses belajar mengajar dan tindak lanjut dari proses belajar mengajar. Bagian ini akan menguraikan bagaimana pelaksanaan proses belajar mengajar secara tatap muka agar tujuan pembelajaran/kompetensi peserta didik tercapai.

Pelaksanaan pembelajaran tatap muka adalah proses mengupayakan siswa belajar, dimana guru siswa dan bahan bertemu secara bersamaan. Dalam hal ini yang terpenting adalah makna pertemuan ketiga komponen itu sehingga berarti. Gagne mengemukakan langkah-langkah pembelajaran sebagai berikut :

a. Menarik perhatian

b. Menyampaikan tujuan pembelajaran

c. Menggambarkan konsep/ prinsip yang telah dipelajari

d. Menyampaikan materi pembelajaran

e. Memberikan bimbingan belajar

f. Memperoleh unjuk kerja siswa

g. Memberikan balikan

h. Menilai hasil belajar

i. Memperkuat retensi dan hasil belajar

Amstrong menekankan proses mengupayakan siswa belajar dengan kondisi berkecerdasan majemuk, melalui kemampuan guru dalam membelajarkan dengan teknik yang berbeda seperti :

a. Mengajar dengan berceritera

b. Memberikan pertanyaan

c. Mengembalikan konsep atau memetakan pikiran

d. Menggunakan gerak isyarat / ekspresi dramatis

e. Menggunakan suara secara berirama

f. Berinteraksi secara dinamis

g. Menghadirkan perasaan dalam presentasi

h. Menghubungkan materi pelajaran dengan fenomena alam

i. Menggunakan masalah-masalah kehidupan.

Memperhatikan bagaimana membelajarkan seperti dikemukakan oleh kedua ahli tersebut, kini guru/dosen tidak layak jika hanya duduk atau berdiri dan berkata-kata. Aplikasinya adalah guru harus kreatif, inovatif dan sistematis.

Contoh perilaku guru yang kreatif dan inovatif::

a. Menggunakan suara, bahasa tubuh

b. Menggunakan musik

c. Menggunakan media / benda nyata d. Memasang poster / gambar / foto di dinding ruangan kelas

e. Menggunakan aroma wewangian

f. Mengatur posisi kursi / meja belajar

g. Membantu kelelahan siswa dengan senam otak

h. Menuliskan catatan penting di papan tulis dengan gambar dan warna

i. Menghindarkan kata-kata negatif

j. Mendorong siswa terlibat aktif berinteraksi

k. Membantu siswa untuk mengkonstruksi pengetahuannya

1. Memberikan bimbingan siswa secara tulus

$\mathrm{m}$. Membantu mengembangkan life skills siswa meliputi ; learning how to thing, learning to do, learning to be, learning to learn, dan learning to live together.

Contoh perilaku guru/dosen membelajarkan secara sistematis adalah :

a. Menggunakan tahapan pembelajaran untuk merealisasikan pengalaman belajar siswa dengan:

1. Pendahuluan, kegiatan inti dan penutup

2. Pra pembelajaran, penyajian, partisipasi siswa, tes dan tindak lanjut

3. Tumbuhkan, alami, namai, demonstrasikan dan rayakan.

b. Memilih metode dan media sesuai dengan pengalaman belajar yang direncanakan.

c. Mengelola waktu sesuai dengan dengan tahapan tahapan pembelajaran dan karakteristik materi pelajaran.

d. Mengoptimalkan penggunaan sarana dan prasarana di lembaga yang tersedia sesuai dengan tujuan pembelajaran / kompetensi yang akan dicapai.

e. Menggunakan sumber-sumber belajar baik yang dirancang (by desaign) dan atau dimanfaatkan (by utulization) untuk kemudahan siswa belajar.

f. Mengelola kelas dan siswa sesuai dengan kegiatan yang direncanakan .

Pelaksanaan pembelajaran dengan contohcontoh perilaku guru/dosen secara kreatif, inovatif dan sistematis harus diikuti dengan kepribadiannya dan penampilan dalam berpakaian, berjalan dan bersikap sehingga kompetensi melaksanakan pembelajarannya efektif.

Di bawah ini adalah sebuah contoh prosedur pembelajaran yang dapat dikembangkan oleh guru/ 
dosen agar membelajarkan secara sistematis dan tidak berdasarkan intuisi.

Prosedur Pembelajaran :

a. Penyiapan kondisi pembelajaran.

b. Menggunakan kegiatan pembelajaran yang sesuai dengan kompetensi/ kriteria unjuk kerja, siswa, materi dan lingkungan.

c. Menggunakan alat bantu pembelajaran yang sesuai dengan kompetensi/kriteria unjuk kerja, siswa, materi dan lingkungan.

d. Melaksanakan kegiatan pembelajaran dalam urutan yang logis.

e. Keterampilan memberi penjelasan/petunjuk yang berkaitan dengan isi pelajaran.

f. Menggunakan variasi stimulus dalam pembelajaran secara tepat.

g. Mendemonstrasikan kemampuan pembelajaran dengan menggunakan metode yang tepat.

h. Upaya guru untuk meningkatkan keterlibatan siswa dalam proses belajar mengajar.

i. Memelihara keterlibatan siswa dalam pembelajaran.

j. Membuat rangkuman/ringkasan materi pelajaran dan memberikan balikan.

k. Efektivitas penggunaan waktu.

1. Penggunaan bahasa.

m. Kepedulian terhadap kesalahan berbahasa siswa.

n. Penampilan guru dalam pembelajaran.

o. Melaksanakan kegiatan evaluasi sesuai dengan kompetensi/kriteria unjuk kerja.

\section{Penilaian Hasil Belajar}

Ketidakpercayaan orang tua, siswa terhadap guru dan sekolah adalah kurangnya sosialisasi standar penilaian hasil belajar Pasal 64, sampai dengan Pasal 72 Peraturan Pemerintah RI No. 19 Tahun 2005, tentang Standar Nasional Pendidikan. Pernyataan tersebut dianalisis dari pengamatan kasus yang terjadi belum lama ini.

Pemerintah sebagai pembuat Peraturan Pemerintah, dan sekolah yang menjembatani kebutuhan pemerintah dan siswa kurang arif dalam prinsip penilaian yang dikembangkan guru yaitu penilaian berbasis kelas. Akibatnya yang menjadi korban adalah siswa. Kontradiksi terjadi lagi dengan disosialisasikannya oleh pemerintah, pendidik, ahli pembelajaran tentang pengakuan bahwa setiap peserta didik memiliki potensi kecerdasan jamak. Artinya individu belajar berkembang dalam kecerdasan bahasa, kecerdasan interpersonal namun kecerdasan logis matematis lebih rendah dari kedua kecerdasan itu. Atau mata pelajaran yang dipelajari di sekolah dan telah diujikan seluruh prestasinya baik, kecuali matematika. Dengan demikian masalah belajar peserta didik ini siapa yang bertanggung jawab. Pemerintah tidak memberi sanksi kepada lembaga sekolah dengan mencabut jabatan Kepala Sekolah. Selain itu kegagalan ini tidak dikaitkan kompetensi guru terhadap penguasaan matematika guru. Manakah yang akan dipilih oleh pemerintah, siswa tumbuh dan berkembang sesuai dengan potensi kecerdasannya atau kebanggaan atas angka-angka. Bukti yang dapat dicermati lagi adalah juara olimpiade matematika, fisika, dimana mereka berkembang dengan dibimbing oleh Bapak Yohanes Surya. Juga keberhasilan UAN, siswa banyak ditunjang oleh orang tua, karena siswa mengikuti bimbingan belajar di luar sekolah. Jadi siapakah yang cerdas, siswa atau guru. Masihkah sekolah merasa bangga dengan status sekolah unggulan, sekolah berstandar nasional. Sudahkan pemerintah ikut serta mengawasi biaya yang dipungut sekolah dari masyarakat pada awal tahun untuk siswa baru?

Komite sekolah belum berperan menjembataninya dengan kualitas pembelajaran. Tampak kelas ber-AC, gedung dicat tetapi campur tangan komite kurang dalam hal kualitas. Sementara laporan keuangan belum terbuka dari pihak sekolah. Kesimpulannya siapakah yang merusak sistem pendidikan dan melanggar manajemen berbasis sekolah.

Mencermati kasus di atas, ada sesuatu yang tidak diperhatikan oleh pelaksana pendidikan, bahwa sistem penilaian hasil belajar tidak konsisten dengan siswa, tujuan pembelajaran dan metode. Hal ini dikemukakan oleh Kemp, Morrison dan Ross pada visual berikut :

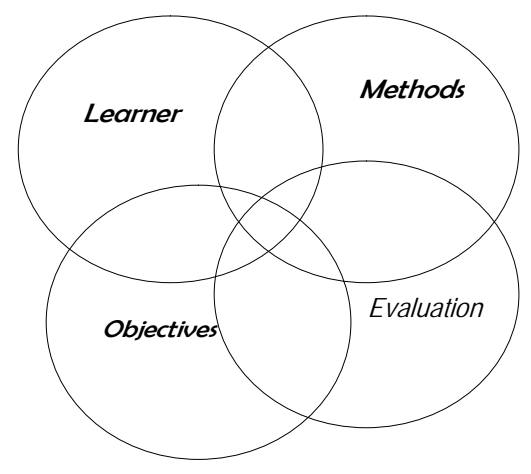

Berdasarkan prinsip ini maka aplikasi penilaian hasil belajar siswa adalah konsisten dan adekuasi dengan siswa, tujuan dan metode. Pendekatan teknologi pendidikan yang digunakan 
adalah berorientasi pada siswa, karena siswa merupakan subyek belajar. Paradigma baru ini belum melekat kepada para pelaksana pendidikan. Evaluasi hasil belajar yang dikembangkan harus konsisten dan adekuasi dengan tujuan pembelajaran. Dengan memperhatikan kriteria kesesuaian dan memadai Ujian Akhir Nasional (UAN) yang dirancang lembaga mandiri belum tercapai dengan kriteria itu. Keadaan ini dapat dianalisis dengan penilaian yang digunakan hanya mengembangkan aspek kognitif, alat ukur tes tertulis serta pengambilan keputusan siswa berhasil hanya dari UAN, tanpa memperhatikan perkembangan kemampuan yang telah dicapai siswa secara terus menerus. Contoh aplikasi ini adalah menilai hasil belajar sebaiknya berprinsip kepada objektivitas dan menyeluruh (penguasaan kompetensi kognitif, aloktif dan psikomotor, serta teknik alat ukur beragam).

Kesesuaian dan adekuasi pada komponen dan metode (cara untuk menyampaikan materi ajar) akan menentukan teknik penilaian. Bila metode yang dipilih diskusi, maka teknik penilainnya adalah penilaian unjuk kerja dari proses berdiskusi dan hasil diskusi. Mengukur proses diskusi dengan cara analitik melalui observasi (kerjasama, keaktifan, bahasa lisan, keterlibatan), hasil diskusi (bahasa tulisan, sistematik, kebersihan, kerapihan, kesesuaian dengan tujuan). Analisis penilaian hasil belajar dari konsep Kemp, dkk ini memberikan pegangan bagi guru/dosen untuk selalu memelihara dan melaksanakan evaluasi hasil belajar secara sistematis.

\section{KESIMPULAN}

Berdasarkan rumusan masalah dan pembahasan disimpulkan:

1. Analisis peserta didik dilaksanakan pada awal kegiatan untuk mengoptimalkan tercapainya tujuan.

2. Pelaksanaan pembelajaran dilakukan guru/ dosen secara sistematis.

3. Penilaian hasil belajar berorientasi kepada si belajar, sesuai dan adekuat dengan tujuan pembelajaran dan metode.

\section{DAFTAR PUSTAKA}

Amstrong, Thomas. (2003). Sekolah para juara: mencapai multiple intellegences di dunia pendidikan. Bandung: Kaifa.

De Porter, B. (2003). Quantum teaching: Mempraktekkan quantum learning di ruang-ruang kelas. Bandung: Kaifa.

Heinich, R., et al. Intructional media and tecnologies for learning. Englewood Cliffs, New Jersey: Prentice Hall, Inc.

Hernowo. (2005). Menjadi guru yang mau dan mampu mengajar secara menyenangkan. Bandung MLC.

. Peraturan Pemerintah R.I. No. 19 Tahun 2005 tentang Standar Nasional Pendidikan. Jakarta : BP Cipta Jaya, 2005.

Kemp, J. E., Morrison, G. R., \& Ross, S. (1994). Designing effective instruction. New York: Mac Millan College Public, Co.

Mulyasa. (2004). Kurikulum berbasis kompetensi: konsep, karakteristik dan implementasi. Bandung PT Remaja Rusda Karya.

Suparman, M. A. (1997). Desain instruksional. Jakarta: PAU PPAI Universitas Terbuka.

Suprayekti. (2004). Interaksi belajar mengajar (untuk Guru Bantu). Depdiknas.

\section{KETERANGAN PENULIS}

Dra. Suprayekti, M.Pd, lahir di Jakarta tahun 1960. Menyelesaikan program S2 di bidang Teknologi Pendidikan Universitas Negeri Jakarta. Saat ini bekerja sebagai staf pengajar di Jurusan Kurikulum dan Teknologi Pendidikan (KTP), dosen untuk mata kuliah MKDK serta AKTA Mengajar dan saat ini pun menjabat sebagai Divisi Akademik LAM UNJ. Selain itu pernah menjabat sebagai Ketua Jurusan KTP. Tulisan yang dihasilkannya cukup banyak, salah satunya berupa buku yang berjudul Interaksi Belajar Mengajar untuk Guru Bantu tahun 2004, selain itu juga menulis diktat untuk mata kuliah Perencanaan Pengajaran di jurusan KTP tahun 2003, juga menulis handout untuk MKDK yaitu Pendekatan Pembelajaran tahun 2005. 